\title{
Sound-Color-Symbolic Perception of Poetic Texts by Synesthets
}

\section{Звукоцветосимволическое восприятие синестетами поэтических текстов}

\author{
Mariya Elivanova ${ }^{1}$ \\ Ph.D. in Philology, \\ Assistant Professor
}

\author{
Мария Еливанова ${ }^{1}$ \\ кандидат филологических наук, \\ доцент
}

E-mail: melivanova@yandex.ru https://orcid.org/0000-0002-9828-7470

\section{Valeria Semushina ${ }^{2}$}

Ph.D. in Philology,

Assistant Professor

\section{Валерия Семушина ${ }^{2}$}

кандидат филологических наук, доцент

E-mail: haleria@yandex.ru https://orcid.org/0000-0003-2321-7352

${ }^{1}$ Herzen State Pedagogical

University of Russia, Department

of Language and Literary

Child Development

48, Embankment of the river

Moika, Saint-Petersburg, Russia, 191186

${ }^{2}$ Institute of Foreign Languages, Department of the English Language $\triangle 13$, Line 12, Vasilievskii ostrov, Saint-Petersburg, Russia, 199178
${ }^{\prime}$ Российский государственный педагогический университет им. А.И. Гериена, кафедра языкового и литературного образования ребенка $\checkmark$ Набережная р. Мойки, 48, Санкт-Петербург, Россия, 191186

${ }^{2}$ Институт иностранных языков, кафедра английского языка 13, 12-я линия, Васильевский остров, Санкт-Петербург, Россия, 199178

Original manuscript received August 12, 2019

Revised manuscript accepted March 31, 2020 


\section{ABSTRACT}

Introduction. The article is devoted to discussing complex synesthets' capability of sound-colour-symbol analysis of poetic texts in order to investigate their perception depending on subconsciousness which activity manifests itself in the form of symbolic images of the unconscious (Jung, 1968).

Research methods. Synesthets were offered the text and the recording of R.L. Stivenson's poem "The Land of Counterpane» in original and variants of its translation by V. Brjusov and $O$. Mandelstam (the last one with recording). The tasks were as follws: to read aloud or to listen to the poems trying not to take into account meaning of words, to describe the colour of the texts depending on sound/letter frequency and to report us their image-symbol associations based on sound-colour of the texts. These data were analyzed from the point of view of Jung's depth analytical psychology and psychology of colour.

Results and their discussion. Sound-colour analysis executed by respondents show that their perception of sound frequency differs depending on individual peculiarities of synesthesia. Synesthets' spontaneous incidental image-symbol associated with sound and colour of the same poems have a tendency to be different in most cases and rarely coincide. Various metaphoric images can have close symbolic meaning determined by poet's primary motivation with help of phonetic means of language expression. Received data show that synesthets' perception depends on the language, the text is written in, and emotionality/inemotionality (characteristic feature offered by one respondent) of reader's manner of reciting in the recording. Image symbols evoked while reading and listening to English and Russian texts can be the same in case the tested person regards the translation more successful.

Conclusion. Image symbols associated by complex synesthts with sound and colour of poetic texts appear in the subconscious on the ground of synesthemia (co-sensation and co-emotion). Sound-colour-symbol perception is determined by individual peculiarities of synesthesia and synesthets' personal experience.

Key words: synesthesia, synesthet, synesthemia, sound, color, subconscious, symbols of the unconscious.

\section{Введение}

C.В. Воронин (1982) полагал, что звукоизобразительные средства языка обусловлены необходимой, существенной и относительно устойчивой фонетически (примарно) мотивированной связью фонем слова с денотатом. При денатурализации языкового знака секундарная семантическая и морфологическая мотивированность компенсирует и вытесняет на периферию значения слова примарную мотивированность, которая сохраняет свои центральные позиции в художественном тексте. Ученый ввел 
в фоносемантику необходимое для теоретического обоснования звукосимволических явлений понятие синестемия, означающее взаимодействие между ощущениями разных модальностей и между ощущениями и эмоциями, результатом которого на первосигнальном уровне высшей нервной деятельности является перенос качества ощущения, а на второсигнальном уровне - перенос значения слов, в том числе звукоизобразительных.

Природа звукоизобразительности языка лежит в подсознании. Как указывал И.Н. Горелов (1985), формирование и функционирование отношений между мотивированностью и немотивированностью происходит на подсознательном уровне, где вербальное сообщение накладывается на предварительно выраженную в нём невербальную систему коммуникации и происходит синестетическое взаимодействие звучания и значения.

Согласно К.Г. Юнгу (Jung, 1968), бессознательное и сознание являются двумя слоями психики, между которыми постоянно происходит обмен впечатлениями, идеями и чувствами, а также существуют отношения компенсации. Бессознательное часто проникает в сознание в виде символических образов, смысл которых бывает непонятен человеку и нуждается в объяснении. Такие образы появляются в сновидениях и могут присутствовать в любых других психических проявлениях подсознания.

Исследуя проблемы коммуникации у животных и человека, Н.И. Жинкин заметил:

«Придется принять, что есть, по меньшей мере, два вида абстракиии - абстракиия интеллектуальная и чувственная. В первом случае образуются понятия о вещах и явлениях действительности, во втором перестраивается восприятие некоторых вещей и явлений действительности. При этом один человек видит и слыпит такие признаки воспринимаемых явлений, которые другой человек не видит и не следит» (1998: 77).

С этой точки зрения, синестеты обладают особыми возможностями звукосимволического восприятия звучания речи.

В современной науке существует смешение понятия синестезии естественного развития с другими явлениями субъективного опыта, основанными на межсенсорных связях - межсенсорными ассоциациями, кроссмодальными метафорами, образами и 
впечатлениями, качества которых соотносятся одновременно с разными органами чувств и которые также принято называть синестезией (Сидоров-Дорсо, 2013). Наряду с объединением обоих понятий (Mulvenna \& Walsh, 2006; Eagleman \& Goodale, 2009) высказывается мнение о необходимости их разграничения (Deroy \& Spence, 2013). Существует обоснованное суждение о том, что кросскорреляционные связи между различными областями мозга объясняют не только явление синестезии, но и креативность, развитие метафорической мысли и самого языка (Ramachandran \& Hubbard, 2001).

У синестетов, наряду с акустически обусловленными изменениями цвета звуков и их сочетаний в словах, наблюдается связь цвета отдельных слов с денотатом (Еливанова, 2018; Еливанова \& Семушина, 2019). Это указывает на возможность одновременного проявления как стимулзависимой проекционной, так и кросскорреляционной ассоциационной синестезии. Такая форма синестезии является комплексной.

Данное исследование направлено на изучение зависимости восприятия поэтических текстов комплексными синестетами от их подсознания, которое может проявляться в символах бессознательного.

\section{Методика исследования}

Исследование проведено с участием трёх синестетов, имеющих художественный тип высшей нервной деятельности по И.П. Павлову и средний уровень эмпатии по EQ-тесту Н. Холла. Взаимодействие с испытуемыми проводилось дистантно, через сеть Интернет. Для анализа им предлагалось стихотворение Р.Л. Стивенсона с фонограммой (YouTube. Bed can be a big adventure! The Land of Counterpane by Robert Louis Stevenson), тексты его переводов В. Брюсова и О. Мандельштама (и фонограмма Одеяльная страна. Роберт Стивенсон. Перевод Осипа Мандельштама).

Задание состояло в том, чтобы, максимально отвлекаясь от смысла слов, прослушать или прочитать текст вслух, описать его колорит в зависимости от часто встречающихся звуков/букв и сообщить о своих образно-символических ассоциациях с звуками и цветом текста. 
Символическое значение возникших у информантов образных ассоциаций объяснялось нами с позиций глубинной аналитической психологии К.Г. Юнга, в основном по словарю символов Г.В. Врублевской (2002). Символическое значение разных оттенков синего и красного цвета приводится по сводке В.Я. Обухова (1996, 1997).

Специальной задачи систематического экспериментального изучения влияния независимых переменных (язык текста, голос читающего его диктора) на звукоцветосимволическое восприятие синестетов не ставилось, сделаны лишь первые наблюдения в этом направлении.

\section{Результаты исследования и их обсуждение}

Опрос трёх комплексных синестетов показал результаты, которые приводятся в сообщениях респондентов.

R.L. Stevenson, The land of counterpane.

When I was sick and lay a-bed, I I had two pillows at my head, | And all my toys beside me lay, | To keep me happy all the day. || And sometimes for an hour or so | I watched my leaden soldiers go, | With different uniforms and drills, | Among the bed-clothes, through the hills; II And sometimes sent my ships in fleets | All up and down among the sheets; | Or brought my trees and houses out, | And planted cities all about. || I was the giant great and still | That sits upon the pillow-hill, | And sees before him, dale and plain, | The pleasant land of counterpane.

ОЛЬГА ТУРЬЕВА. Графемно-фонемный синестет с соощущениями цвета и фактуры звуков. Английским не владеет, в средней и высшей школе изучала немецкий язык. Неоднократно прослушала стихотворение, отслеживая по тексту и не понимая слов. Текст видится как ТКАНЬ и начинается с НЕБЕСНО-ГОЛУБОГО ЦВЕТА, далее цвет темнеет до ТЕМНО-СИНЕГО, но потом снова переходит в более светлый тон. Из-за сочетаний $\mathrm{OU}$ и звука $\mathrm{S}$ создаётся впечатление, что ТКАНЬ ВЯЗАНАЯ. В первой строфе много S, А и Е, она небесно-голубая. Во второй строфе появляются буквы F, T и D, они затемняют светлые $\mathrm{A}, \mathrm{E}$ и О. В последней строке строфы много тёмных согласных, поэтому она темно-синяя. 
Затем за счёт светлых гласных цвет светлеет, в конце он снова нежно-голубой. Ассоциация возникла со свободой. Тёмная полоса это некие тёмные времена или затруднения в жизни, после которых снова будет РАССВЕТ и СВОБОДА. Текст кажется наполненным ВОЗДУХОМ и лёгкостью, в то же время он непростой и какой-то извилистый, как СВЯЗАННАЯ НИТЬ.

О. Турьевой был предложен также текст дословного перевода стихотворения на русский язык:

«Когда я был болен и лежал в кровати, / у моей головы были две подушки / И все мои игрушки около меня лежали, / Чтобы я был счастлив (доволен) весь день. // И иногда примерно час / Я смотрел, как ходят мои оловянные солдатики / В разной униформе, проходя строевое обучение, / В постельном белье через холмы; // И иногда отправлял мои корабли-флотилии / Вверх и вниз по простыням; / Я выставлял деревья и дома, / Располагал везде города. // Я был великим и неподвижным великаном, / который сидит на холме из подушки / И смотрит перед собой на долины и степи, / Приятную землю стеганого одеяла».

Она сообщила, что при чтении все время присутствовал песчаный цвет, потому что в тексте много светло-жёлтых букв О и есть буквы Ж и Г, окрашивающие текст в оранжево-коричневый цвет. Со звучанием и цветом текста ассоциируется слово «ОПТИМИЗМ».

ТАНИТА ГРИЦЕНКО. Фонемно-графемный синестет с соощущениями цвета и фактуры звучания. Практикующий учитель английского языка, окончила факультет иностранных языков. Сообщила, что есть большая разница в восприятии прослушанного и прочитанного текста. На слух лучше воспринимается цвет слов, на который оказывает влияние лишь часть составляющих их звуков. Стихотворение окрашено в темные тона, большинство слов имеет коричневую окраску, часто встречаются также серые и черные. Из общего цветового фона выделяются слова dale и plain. Эти слова имеют доминантный белый цвет и являются белыми. В слове dale имеется также РОЗОВЫЙ ЦВЕТ, и непонятно, откуда он. Выразительное эмоциональное чтение текста диктором вызывает яркие богатые образы. В стихотворении ощущается что-то шелковое, таинственное, звездное и темное, похожее на НОЧНОЕ ЗВЕЗДНОЕ НЕБО, которое простирается, как ШЕЛКОВАЯ 
ТКАНЬ. Мягкий бархатный тембр голоса диктора и его интонации передают НОЧНОЕ ТАИНСТВО, тёплые и тёмные оттенки. Символы прослушанного: ТАИНСТВО (ПОКРОВ) НОЧИ, ЗВЕЗДЫ, ДОЛИНА, БЕРЕГ.

При самостоятельном чтении стал возможным учёт влияния цвета букв (обращает внимание не на высокую частоту букв, а на преобладающие цвета). Написанный вариант текста весь черный $(\mathrm{O}, \mathrm{I})$ и коричневый $(\mathrm{H}, \mathrm{P}, \mathrm{U})$ с зеленым $(\mathrm{B}, \mathrm{N}, \mathrm{W}$ - одна эта буква делает зелёным всё слово watched), есть синие места от разных оттенков синих S, F и L. Цвет фразы «Among the bed-clothes, through the hills» понять сложно, так как цветовая гамма ускользает. Видится нечто светлое, почти бежевое, с белыми и коричнево-черными оттенками. Все это в причудливых формах, что-то вроде пирамиды. «All up and down among the sheets» - подобная же ПИРАМИДА оттенков, но всё мимолётно и описать не получается. В белоголубом слове dale имеется непонятного происхождения РОЗОВЫЙ ЦВЕТ, который на письме несколько теряется. В белом и розовоголубом слове land розовых букв нет, белый цвет даёт А и голубой L, жёлтая буква D утрачивает свой цвет. По ассоциации со звуками и цветом текста на ум пришли слова «ОДЕЯЛЬНЫЕ ДОЛИНЫ».

ЛЮДМИЛА ПОЛОНСКАЯ. Графемный цветовой синестет (окрашены графемы, звуки внешнего происхождения цвета не имеют) с соощущениями фактуры, температуры и пространства в звучании текста. Свободно владеет английским языком, 5 лет жила в США, в настоящее время редко пользуется английской речью в устной форме. Читая вслух, неожиданно для себя выяснила, что цвет букв связан со звуком. Например, английская буква Р тёмнорозовая, как русская Р, но при озвучивании слова (например, pillow) графема приобретает темно-фиолетовый цвет, как у русской буквы П. Непроизносимые буквы имеют цвет только при взгляде на текст, при чтении вслух их цвета исчезают. В слове hour, например, на тексте виден цвет первой нечитаемой буквы $\mathrm{H}$ (розово-коричневый), а при озвучивании слова воспринимается первым алый цвет звука А. Буква В при озвучивании обретает светло-салатовый оттенок, как русская буква Б, на тексте цвет темнеет и соответствует русской В. Цвет буквенного сочетания ТН приглушённого серого цвета, нечто среднее между серебристой $\mathrm{C}$ и графитовой Т. Гибридный цвет этих двух букв здесь соответствует 
звуку. Буква W имеет бирюзовый цвет, средний между серо-голубой $\mathrm{U}$ и зеленой $\mathrm{V}$, но только если читается. В конце слова pillow она не передает отдельного звука и становится почти бесцветной. Сделала вывод о том, что сама по себе буква - это просто знак, а цвет привязан к звуку, который она символизирует. Цвет при взгляде на букву возникает в мозге (в подсознании) потому, что её вид ассоциирован со звуком, а тот - с цветом.

В прослушанной фонограмме часто встречаются передаваемые сочетанием букв ТН звонкий и глухой звуки, которых в русском языке нет. Они дают ощущение ПРЕПЯТСТВИЯ - мягкого ХОЛМА, который МЕШАЕТ на пути и его надо ПРЕОДОЛЕТЬ, замедлив ход (как будто ЛЕЖАЧИЙ ПОЛИЦЕЙСКИЙ на дороге). Текст неровный, будто идёшь по ХОЛМАМ (в тексте дважды упоминается слово hill). Много соответствующего букве Н звука, который даёт ощущение прохладного ВЕТРА, вздымающего мелкий ПЕСОК над ДОРОГОЙ.

В. Брюсов. Страна кровати.

Когда я много дней хворал, / На двух подушках я лежал, / И чтоб весь день мне не скучать, / Игрушки дали мне в кровать. / Своих солдатиков порой / Я расставлял за строем строй, / Часами вёл их на простор - / По одеялу между гор. // Порой пускал я корабли; / По простыне их флоты или; / Брал деревямки иногда / И всюду строил города. / А сам я был как великан, / Лежаший над раздольем стран - / Над морем и громадой скал / Из простыни и одеял!

ОЛЬГА ТУРЬЕВА. Стихотворение В. Брюсова не определяется одним каким-то цветом. Он скорее пестрый. Первая строка желточерная, так как много светло-жёлтой $\mathrm{O}$ и тёмных согласных. Третья строка зелено-синяя из-за голубовато-зелёной Е и синих С и Н. Пятая снова желто-черная. Остальные строки строфы видятся светло-желтыми, так как грязно-желтая буква Ч осветляется последующими белыми буквами А и жёлтыми О. Вторая строфа более темная по цвету, так как букв с темной окраской намного больше (П, Р, Й, К, И, Ф, Т, Д, Б, Г, В). Эти буквы или просто черные, или (Б, Г, В) коричневатые. На четвертой строке наступает просветление, появляется больше цвета гласных, пятая строка еще светлее, ее осветляет часто встречающийся белый гласный А. Конец стихотворения пестрит желто-черными красками с вкраплениями 
зелено-синего. Перевод похож на лесенку, он какой-то угловатый и ассоциируется со СТУПЕНЯМИ ЛЕСТНИЦЫ.

ТАНИТА ГРИЦЕНКО. Перевод В. Брюсова более светлый, чем английский текст, в нём больше светлых оттенков. Стихотворение окрашено в коричнево-черно-серый с белым, в нём есть желтые и синие цвета. Всё в темных тонах из-за букв П, Х, У (они придают коричневый цвет), О, Ч, Й, Ы (придают черный и серый). Т, А и Е дают белый, К, Ж, Д, Г - жёлтый, С и Ш - темный синий и синевато-серый. Воображаются МОРЕ, ДОЛИНА, БЕРЕГ.

ЛЮДМИЛА ПОЛОНСКАЯ. Как и в случае английского текста, в целом стихи В. Брюсова в момент чтения не имеют цвета. Цвет появляется при чтении взятых по отдельности слов, если их мысленно озвучить (артикулировать). Иногда слово целиком окрашивается стоящей в начале или доминирующей буквой. Некоторые слова имеют свой собственный цвет, связанный с цветом денотата. Звукосимволическое впечатление от текста такое, как будто идёт по земле под ДУБОМ, кругом валяются упавшие ЖЁЛУДИ это буква Д, она желудёвого цвета, светло-желтого с оттенком бежевого. («Дубовая буква», по выражению Л. П.). Выделяются цветом строки: «Своих солдатиков порой / Я расставлял за строем строй». Много свистящего С (эта буква неестественно серебристого цвета и светится), поэтому строки похожи на СЕРЕБРЯНЫЙ ШНУР.

О. Мандельштам. Одеяльная страна.

Лёг в кровать. Закутался. Согрелся. / Подавайте мне теперь сюда / Все игрушки - кубики и рельсы, / Корабли, сады и города. // Два холма - под одеялами коленки, / И простьнь бушует океан. / Города и башни ставлю к стенке / На крутой подушечный курган. // По холмам двойного одеяла, / По горам подушечной страны / Оловянная пехота пробежала / И прошли индийские слоны. // Я гляжу, как ласковый хозяин, / Как хороший, добрый великан, / На равнину шерстяных окраин / И на полотняный океан.

ОЛЬГА ТУРЬЕВА. В целом перевод О. Мандельштама песочно-желтого цвета. В первой строфе текста окраску придают буквы О - жёлтая, У - оранжевая, Ю - кирпичного цвета; это очень сильные гласные. Вторая строфа как будто светлеет и становится бежевой. Третья строфа отдает немного зеленоватым оттенком. Четвертая возвращается в светло-желтый цвет из-за часто 
повторяющихся О. Стихи обтекаемые и ассоциируются почему-то с ТЁПЛЫМ ЛЕТНИМ ВЕЧЕРОМ И КРАСНЫМ ЗАКАТОМ НА НЕБЕ. С воспринятым на слух текстом разница большая. Голос чтеца-декламатора окрасил стихотворение в тёмный цвет. Оно выглядит в его исполнении как ШТРИХОВОЙ КОД (графическая информация о товаре в виде полос разной ширины).

ТАНИТА ГРИЦЕНКО. Текст стихотворения О. Мандельштама имеет больше коричневых оттенков с желтыми вкраплениями. В тексте много коричневых букв П, Ы, У и черных О и И, есть немалый процент белого из-за А, Е, Т, Б. Но тут и желтого уже больше из-за букв Д, К, Г. Есть голубой Л. Поэтому текст данного стихотворения светлее. Представляется ДОМ, КРОВАТЬ, СВЕТ ЛАМПЫ. На видеоролике очень невыразительное чтение стихов лишено эмоций и ощущений цвета не даёт. При прослушивании фонограммы СТЕНА какая-то непонятная, тёмная видится и за ней - ничего. Никаких образов.

ЛЮДМИЛА ПОЛОНСКАЯ. В стихотворении О. Мандельштама некоторые слова окрашиваются в момент чтения аллитерацией. В фрагменте «крутой подушечный курган» два крайних слова имеют яркие буквы К и Р, которые придают строке красно-розовый цвет. Строка урчит и перекатывается, как крутые ЯЙЦА или грецкие ОРЕХИ, и напоминает брачное курлыканье (воркование) ГОЛУБЯ. Слово «подушечный» начинается с темно-баклажановой буквы П, она первая в слове и могла бы окрасить его целиком, но мысленно произнесённое слово почти не окрашено, мешает буква Ш (почти бесцветная, с мышино-серым оттенком). В тексте много Ш и Х, поэтому чувствуется какая-то ШЕРШАВАЯ ПОВЕРХНОСТЬ, как у ТКАНОГО синтетического коврика. К концу нарастает частота Л (эта буква имеет ненатуральный прозрачный желто-зеленый цвет), поэтому видится ПОЛОЩУЩИЙСЯ на ВЕТРУ прозрачный жёлто-зелёный ФЛАГ, который освещён СОЛНЦЕМ. Шершавость текста уступает место СВОБОДЕ, ВЕТРУ И ДВИЖЕНИЮ. О поэте написала: «"И звуков стакнутых прелестные двойчатки". Возможно, Мандельштам был синестетом, сам не подозревая этого».

При прослушивании фонограммы заметила, что в тексте много звука С, вплетённого как блестящая СЕРЕБРЯНАЯ НИТЬ в ТКАНЬ стихотворения (слушая стихотворение Р.Л. Стивенсона, не обратила внимания на обилие $\mathrm{S}$ в тексте по причине «препятствий на пути 
восприятия»). Образные ассоциации прежние, но возникли и новые образЫ - САДЫ и РЕЛЬСЫ.

Сообщения синестетов комментировались нами с позиций глубинной аналитической психологии (Jung, 1968) и психологии цвета (Lüscher, 2005). Проведенный анализ сообщений позволил обнаружить действие законов фоносемантики при восприятии стихотворных текстов респондентами.

Bce комплексные синестеты образуют ассоциации с звукоцветом текста, образные или же абстрактные (СВОБОДА, ОПТИМИЗМ, ТАИНСТВО, ДВИЖЕНИЕ, ПРЕПЯТСТВИЕ), представляющие собой продукт осознания смысла образов.

ОЛЬГА ТУРЬЕВА с звукоцветом текста Р.Л. Стивенсона ассоциировала ТКАНЬ, символизирующую качество жизни. Тип ткани обозначает характер переживаний, они «вязаные». Узоры на поверхности ткани - сами переживания. СИНИЙ ЦВЕТ - цвет неба, он создаёт чувство безопасности, доверия и покоя, освобождает от тревог. НЕБЕСНЫЙ ГОЛУБОЙ - символ спокойствия, свободы и беззаботности. ТЁМНО-СИНИЙ цвет имеет здесь негативное значение и осознаётся как тёмная полоса в жизни. РАССВЕТ означает победу света над тьмой, дня над ночью, надежду. ВОЗДУХ - это символ свободы духа, творчества, способности подняться над проблемами и найти их решение. НИТЬ символизирует связь тела и духа, неба и земли. Порвать нить значит потерять какую-то часть себя. СВЯЗАННАЯ НИТЬ означает поэтому восстановленную целостность «я».

ТАНИТА ГРИЦЕНКО, прослушав этот же текст, в качестве символа его звуков и цвета назвала шёлковую ТКАНЬ (мягкую, гладкую) с узором в виде ночного звёздного неба. НЕБО означает душевное состояние в соотношении с его видом. Красивое небо гармония и лёгкость чувств. ЗВЁЗДНОЕ НЕБО символизирует врата в незнаемое. НОЧЬ как символ связана с таинственной тьмой и материнским лоном. ПОКРОВ - с сокрытием определённых аспектов истины. ЗВЕЗДА - знак судьбы, устремление в будущее и уход от реальных проблем. ДОЛИНА - ограниченное пространство и период счастья или имеющего границы бедствия. БЕРЕГ прочность и ожидание благих перемен. В анализе печатного текста фигурируют ПИРАМИДА - символ некоей тайны и знания, а также «ОДЕЯЛЬНЫЕ ДОЛИНЫ». ОДЕЯЛО выражает потребность в 
защите, скрытые мысли, невидимые обстоятельства. В словах dale и land РОЗОВЫЙ ЦВЕТ олицетворяет собой детство, жизнь в мире грёз, отвлечение от плохих мыслей и успокоение.

ЛЮДМИЛА ПОЛОНСКАЯ указала на такие возникшие у неё под влиянием фонограммы текста Р.Л. Стивенсона символические образы, как ХОЛМ - образ дважды эксплицитно присутствует в тексте стихотворения и олицетворяет собой «место человека под солнцем», и ВЕТЕР - символ «ветра перемен». Эти символы фонетически обусловлены речью поэта. ДОРОГА - жизненный путь на данном этапе (чей? автора? реципиента!). ЛЕЖАЧИЙ ПОЛИЦЕЙСКИЙ - препятствие на пути, ПЕСОК - мелкие привычные раздражения (огорчения) при встрече помех и препятствий на своём пути.

У ОЛЬГИ ТУРЬЕВОЙ при чтении стихотворения В. Брюсова по ассоциации возник образ ЛЕСТНИЦЫ, символизирующей связь верха и низа, движение к своему желанию. Движение вверх по лестнице означает развитие ума и интуиции, вниз - углубление в тайны своей души. Ведущие вверх СТУПЕНИ ЛЕСТНИЦЫ отражают устремления поэта (вспомнилось стихотворение «Лестница», где он пишет о себе: «Всё каменней ступени. / Всё круче, круче всход. / Желанье достижений / Ещё влечёт вперёд»).

ТАНИТА ГРИЦЕНКО с данным переводом ассоциирует в образной форме МОРЕ - символ тайны, могучей силы, эмоционального и творческого подъёма, стихии бессознательного. Как и в отношении стихотворения Р.Л. Стивенсона, у неё здесь возникли также образы ДОЛИНЫ и БЕРЕГА.

ЛЮДМИЛА ПОЛОНСКАЯ ассоциировала с текстом стихотворения В. Брюсова ЖЁЛУДЬ (во множественном числе), символизирующий потенциал для будущих дел, ДУБ, который олицетворяет собой силу характера и стойкость, и сияющий СЕРЕБРЯНЫЙ ШНУР - символ связи души и тела.

ОЛЬГА ТУРЬЕВА связала текст стихотворения О. Мандельштама с тёплым летним вечером и красным закатом на НЕБЕ (символ душевного состояния). ЛЕТО символизирует зрелость, силу и энергичность, ВЕЧЕР - ожидание новых событий и необходимость завершить какие-то дела. ЗАКАТ служит символом завершения какого-то этапа в жизни, надежды на светлое будущее. КРАСНЫЙ ЦВЕТ по своему значению имеет две стороны. 
С одной - это символ любви, красоты, вдохновения и активной жизненной силы, с другой - он связан с кровью, агрессией и запретом. Психологически этот цвет соответствует сангвиническому темпераменту, эмоциональности, мужественности, уверенности и помогает легче перенести неприятности.

У ТАНИТЫ ГРИЦЕНКО ДОМ - это символ её внутреннего Эго и области его сознательных интересов, может отражать также проблемы тела, мысли, чувства, духа. КРОВАТЬ у неё отображает болезнь или усталость. ЛАМПА - символ управляемого света, приносящего радость. Мягкий СВЕТ ЛАМПЫ - счастье и радость, которые для больного могут быть предвестником выздоровления. СТЕНА - это символический образ непреодолимого затруднения, вызванного монотонностью голоса на фонограмме при изустном восприятии стихотворения О. Мандельштама.

ЛЮДМИЛА ПОЛОНСКАЯ сообщила о переводе О. Мандельштама, что его начало ассоциируется с ШЕРШАВОЙ поверхностью ТКАНОГО изделия, что указывает на «шершавость» закодированных фонетически переживаний поэта. К концу стихотворения в сознании синестета появляется ФЛАГ, который символизирует национально-патриотические чувства. ФЛАГ КОЛЫШЕТСЯ на ВЕТРУ, что означает непроизвольно посланный поэтом фонетическими средствами языка призыв о помощи. СОЛНЦЕ выступает в качестве символа духовной активности, пылкости в реализации проектов, а ВЕТЕР олицетворяет желание автором текста «ветра перемен». Респондент особо выделила фразу «крутой подушечный курган». По ассоциации с ней названы ЯЙЦА и ОРЕХИ, а также ГОЛУБЬ. ЯЙЦО символизирует возникновение идеи. МНОГО ЯИЦ означает беспокойство, а также неопределённость ситуации. ОРЕХ - знак умеренной обеспеченности, жизни без излишеств. ГОЛУБЬ - символ Святого Духа, души поэта, благой вести. СЕРЕБРЯНАЯ НИТЬ означает соединение души с телом, ТКАНЬ - качество жизни. САД символизирует идеальный мир, потерянный рай. РЕЛЬСЫ ожидание перемен, на которые самому поэту невозможно повлиять.

Фоносемантический анализ текстов основан на обнаружении высокочастотных звуков/букв. Синестеты не совпадают в своей спонтанной субъективной оценке частоты звуков в одном и том же стихотворении, зачастую обращая внимание на высокую частотность 
разных звуков/букв (Т. Гриценко вообще обращает внимание не на частоту звуков, а обобщает их по цвету). Это объясняется разнообразием индивидуальных особенностей синестезии (Еливанова \& Семушина, 2018). Разное восприятие синестетами звукоцвета одного и того же стихотворения приводит к тому, что образные ассоциации у них чаще всего отличаются и только изредка совпадают. Различающиеся метафорические образы могут иметь близкое символическое значение, навеянное заложенной в текст фонетическими средствами языка непроизвольной примарной мотивацией автора. Интерпретация образных символов возможна в большинстве случаев с учётом содержания стихотворения, знания обстоятельств жизни и личностных качеств поэта. Проявляются также факторы, исходящие от самого синестета или диктора.

Одни и те же символические образы возникают у синестета при звукоцветосимволическом анализе стихотворения Р.Л. Стивенсона и его русских переводов в том случае, когда перевод признаётся более удачным. Перевод В. Брюсова, по мнению Т. Гриценко, более удачен, он ассоциируется ею с теми же символическими образами, что и английский текст Р.Л. Стивенсона. О. Турьева более удачным считает перевод О. Мандельштама, который по своему образному и художественному строю, мелодике и ритму облегчённого хорея заметно отличается от ямбических стихов Р.Л. Стивенсона. Поэтому НЕБО - одинаковый у неё для обоих стихотворений символический образ - приобретает соответствующий темпераменту и настроениям поэта-переводчика красный цвет. Л. Полонской более удачным кажется перевод О. Мандельштама, поэтому при звукосимволическом анализе двух стихотворений она упоминает ВЕТЕР. В её разборе стихотворений В. Брюсова и О. Мандельштама также присутствует один и тот же метафорический образ - СЕРЕБРЯНЫЙ ШНУР (НИТЬ), символ соединения души и тела при реинкарнации.

\section{Выводы}

Ассоциированные комплексными синестетами со звукоцветом текстов стихотворений символические образы возникают в подсознании на основе синестемии - соощущений и соэмоций. 
Звукоцветосимволическое восприятие текста детерминируется индивидуальными особенностями синестезии и личным опытом синестета.

\section{Благодарность}

Авторы выражают благодарность синестетам за проделанный труд по звукоцветосимволическому анализу текстов стихотворений.

\section{Литература}

Воронин, С.В. (1982). Основы фоносемантики. Ленинград: ЛГУ.

Врублевская, Г.В. (2002). Пять уроков по толкованию снов. Санкт-Петербург: Литера.

Горелов, И.Н. (1985). Невербальные компоненты коммуникации. Москва: Наука.

Еливанова, М.А. (2018). Звуко-цветовой и фоносемантический анализ литературно-поэтического текста синестетами. Psycholinguistics, 24 (2), 4762. https://doi.org/10.31470/2309-1797-2018-24-2-47-62

Еливанова, М.А., \& Семушина, В.А. (2018). Разнообразие звуко-цветовых соответствий в алфавите у синестетов. Уральский филологический вестник, 2 (27), 172-178.

Еливанова, М.А., \& Семушина, В.А. (2019). Фоносемантическая неоднородность поэтических текстов со смысловой альтернативностью в восприятии синестетов. Психолингвистические аспекты изучения речевой деятельности. Труды Уральского психолингвистического общества, 17, 105-115.

Жинкин, Н.И. (1998). Язык - речь - творчество. Избранные труды. Москва: Лабиринт.

Обухов, Я.Л. (1996). Красный цвет. Журнал практического психолога, 5, 39-47.

Обухов, Я.Л. (1997). Синий цвет. Журнал практического психолога, 1, 30-41.

Сидоров-Дорсо, А.В. (2013). Современные исследования синестезии естественного развития. Вопросы психологии, 4, 1-11.

Deroy, O., \& Spence, C. (2013). Why we are not all synesthetes (not even weekly so). Psychon Bull Rev, 204, 643-664. https://doi.org/10.3758/s13423-013-0387-2

Eagleman, D.M., \& Goodale, M.A. (2009). Why color synesthesia involves more than color. Trends in Cognitive Sciences, 13, 288-292. https://doi.org/10.1016/j. tics.2009.03.009

Jung, C.G. (1968). Zugang zum Unbewussten. Der Mensch und seine Symbole (p. 18 103). Olten: Walter-Verlag.

Lüscher, Max. (2005). Der Vier-Farben-Mensch. Ullstein Taschenbuch.

Mulvenna, C.M., \& Walsh, V. (2006). Synaesthesia: Supernormal integration? Trends in Cognitive Sciences, 10 (8), 350-352. https://doi.org/10.1016/j.tics.2006.06.004

Ramachandran, V.S., \& Hubbard, E.M (2001). Synaesthesia: A Window Into Perception, Thought and Language. Journal of Consciousness Studies, 8 (12), 3-34. 


\section{References}

Voronin, S.V. (1982). Osnovy fonosemantiki [Principles of Phono-semantics]. Leningrad: LGU [in Russian].

Vrublevskaja, G.V. (2002). Pjat urokov po tolkovaniju snov [Five Lessons on the Interpretation of Dreams]. Saint-Petersburg: Litera [in Russian].

Gorelov, I.N. (1985). Neverbalnye komponenty kommunikacii [Non-verbal Components of Communication]. Moscow: Nauka [in Russian].

Elivanova, M.A. (2018). Zvuko-cvetovoj i fonosemanticheskij analiz literaturnopojeticheskogo teksta sinestetami [Sound-color and phono-semantic analysis of literary poetic text by synesthets]. Psykholinhvistyka - Psycholinguistics, 24 (2), 47-62. https://doi.org/10.31470/2309-1797-2018-24-2-47-62 [in Russian].

Elivanova, M.A., \& Semushina, V.A. (2018). Raznoobrazie zvuko-cvetovyh sootvetstvij $\mathrm{v}$ alfavite u sinestetov [Diversity of Synesthetes' Sound-color Correspondences in the Alphabet]. Uralskij filologicheskij vestnik - Ural philological Bulletin, 2 (27), 172-178 [in Russian].

Elivanova, M.A., \& Semushina, V.A. (2019). Fonosemanticheskaja neodnorodnost pojeticheskih tekstov so smyslovoj alternativnostju $\mathrm{v}$ vosprijatii sinestetov [Phonosematic Heterogeneity of Poetic Texts with the Semantic Alternatives in Synesthetes' Perception]. Psiholingvisticheskie aspekty izuchenija rechevoj dejatelnosti. Trudy Uralskogo psiholingvisticheskogo obshhestva Psycholinguistic Aspects of the Study of Speech Activity. Works of the Ural Psycholinguistic Society, 17, 105-115 [in Russian].

Zhinkin, N.I. (1998). Jazyk - rech - tvorchestvo. Izbrannye trudy [Language speech - creation. Selecta]. Moscow: Labirint [in Russian].

Obuhov, Ja.L. (1996). Krasnyj cvet [Red color]. Zhurnal prakticheskogo psihologa Journal of Practical Psychologist, 5, 39-47 [in Russian].

Obuhov, Ja.L. (1997). Sinij cvet [Blue color]. Zhurnal prakticheskogo psihologa Journal of Practical Psychologist, 1, 30-41 [in Russian].

Sidorov-Dorso, A.V. (2013). Sovremennye issledovanija sinestezii estestvennogo razvitija [Modern Studies of Synesthesia of Natural Development]. Voprosy psihologii - Question of Psychology, 4, 1-11 [in Russian].

Deroy, O., \& Spence, C. (2013). Why we are not all synesthetes (not even weekly so). Psychon Bull Rev, 204, 643-664. https://doi.org/10.3758/s13423-013-0387-2

Eagleman, D.M., \& Goodale, M.A. (2009). Why color synesthesia involves more than color. Trends in Cognitive Sciences, 13, 288-292. https://doi.org/10.1016/j. tics.2009.03.009

Jung, C.G. (1968). Zugang zum Unbewussten. Der Mensch und seine Symbole (p. 18103). Olten: Walter-Verlag.

Lüscher, Max. (2005). Der Vier-Farben-Mensch. Ullstein Taschenbuch.

Mulvenna, C.M., \& Walsh, V. (2006). Synaesthesia: Supernormal integration? Trends in Cognitive Sciences, 10 (8), 350-352. https://doi.org/10.1016/j.tics.2006.06.004

Ramachandran, V.S., \& Hubbard, E.M (2001). Synaesthesia: A Window Into Perception, Thought and Language. Journal of Consciousness Studies, 8 (12), $3-34$. 


\section{АННОТАЦИЯ}

Введение. Изучалась способность комплексных синестетов к звукоцветосимволическому анализу поэтических текстов с целью исследования зависимости их восприятия от подсознания, деятельность которого выражается в форме имеющих символическое значение образов бессознательного (Jung, 1968).

Методы исследования. Синестетам предлагались текст и фонограмма стихотворения Р.Л. Стивенсона "The Land of Counterpane», тексты его русских переводов В. Брюсова и О. Мандельштама (последний с фонограммой). Задание состояло в том, чтобы, максимально отвлекаясь от смысла слов, прослушать или прочитать текст вслух, описать его колорит в зависимости от часто встречающихся звуков/букв и сообщить о своих образно-символических ассоциациях со звукоцветом текста. Сообщения респондентов анализировались с позиций глубинной аналитической психологии К.Г. Юнга и психологии цвета.

Результаты и их обсуждение. Проделанный респондентами звукоцветовой анализ текстов показал, что восприятие частотности звуков у них различается вследствие индивидуальных особенностей синестезии. Спонтанные непроизвольные образно-символические ассоциации со звучанием и цветом одного и того же стихотворения у респондентов чаще различны и только иногда совпадают. Различающиеся метафорические образы могут иметь близкое символическое значение, связанное $c$ заложенной в текст фонетическими средствами языка непроизвольной примарной мотивацией, которая исходит от поэта. Полученные данные показывают, что восприятие синестетов зависит от того, на каком языке создан текст, и от эмоциональности/неэмоциональности (характеристика дана респондентом) его декламации чтецом на фонограмме. Вызванные чтением и прослушиванием английского и русских текстов символические образы могут быть одинаковы в том случае, когда перевод признаётся испытуемым более удачным.

Выводы. Ассоциированные комплексными синестетами с звучанием и цветом поэтических текстов символические образы возникают в подсознании на основе синестемии (соощущений и соэмоций). Звукоцветосимволическое восприятие текстов детерминировано индивидуальными особенностями синестезии и личным опытом синестета.

Ключевые слова: синестезия, синестет, синестемия, звук, ивет, подсознание, символы бессознательного.

\section{Еліванова Марія \& Семушина Валерія. Звукокольоросимволічне сприймання синестетами поетичних текстів}

\section{АНОТАЦІЯ}

Вступ. Вивчалась здатність комплексних синестетів до звукокольоросимволічного аналізу поетичних текстів з метою дослідження залежності їх сприйняття від підсвідомості, діяльність якої виражається у формі образів несвідомого, що мають символічне значення (Jung, 1968). 
Методи дослідження. Синестетам пропонувалися текст і фонограма вірша Р.Л. Стівенсона "The Land of Counterpane», тексти його російських перекладів, здійснених В. Брюсовим і О. Мандельштамом (останній з фонограмою). Завдання полягало в тому, щоб, максимально відволікаючись від смисла слів, прослухати або прочитати текст уголос, описати його колорит залежно від найпоширеніших звуків/букв і повідомити про свої образно-символічні асоціації зі звукокольором текста. Висловлювання респондентів аналізувалися з позицій глибинної аналітичної психології К.Г. Юнга і психології кольору.

Результати та їх обговорення. Здійснений респондентами звуко-колірний аналіз текстів показав, що сприйняття частотності звуків у них відрізняється через індивідуальні особливості синестезії. Спонтанні мимовільні образно-символічні асоціації зі звучанням і кольором одного й того ж вірша у респондентів частіше різні, і тільки іноді збігаються. Розрізнені метафоричні образи можуть мати близьке символічне значення, пов'язане із закладеною в текст фонетичними засобами мови мимовільною примарною мотивацією поета. Отримані дані показують, що сприйняття синестетів залежить від того, якою мовою створено текст, а також від емоційності/неемоційне (характеристика дана респондентом) його декламування виконавцем на фонограмі. Викликані читанням і прослуховуванням англійською та російською мовами текстів символічні образи можуть бути однаковими в тому випадку, коли переклад визнається досліджуваним найбільш вдалим.

Висновки. Асоційовані комплексними синестетами із звучанням і кольором поетичних текстів символічні образи виникають у підсвідомості на основі синестемії (співвідчуттів і співемоцій). Звукокольоросимволічне сприйняття текстів детерміноване індивідуальними особливостями синестезії і особистим досвідом синестета.

Ключові слова: синестезія, синестет, синестемія, звук, колір, підсвідомість, символи несвідомого. 